\title{
PENGARUH PEMBERIAN EKSTRAK UBI UNGU (Ipomeae Batatas $l$ ) TERHADAP PENURUNAN KADAR KOLESTEROL TOTAL PADA SERUM TIKUS WISTAR (Rattus novergicus) YANG DIBERI INDUKSI KUNING TELUR PUYUH Lufthy Dwi Putra Hutagalung, ${ }^{1}$ Irfan Hamdani. ${ }^{2}$ ${ }^{1}$ Mahasiswa Universitas Muhammadiyah Sumatera Utara ${ }^{2}$ Bagian Anestesi Universitas Muhammadiyah Sumatera Utara Lufthy.Dwi.Putra@icloud.com
}

\begin{abstract}
ABSTRAK
Kata Pengantar: Hiperkolesterolemia dan stres oksidatif masih merupakan masalah kesehatan hingga kini karena berkaitan dengan timbulnya kelainan kardiovaskular dengan berbagai komplikasi. Masyarakat Indonesia telah banyak memanfaatkan berbagai jenis tanaman yang dapat digunakan sebagai alternatif untuk menunjang kesehatan. Dalam beberapa penelitian telah di temukan beberapa tanaman yang dapat menurunkan kadar kolesterol darah, salah satunya adalah Ubi ungu (Ipomea batatas).Tujuan penelitian ini untuk mengetahui bagaimana efek ekstrak daging buah ubi ungu (Ipomea batatas) dapat menurunkan kadar kolesterol total pada tikus wistar yang mengalami dislipidemia. Metode: Penelitian ini adalah penelitian True experimental, dengan rancangan penelitian yang digunakan adalah Post Test Only Control Group Design. Hasil : Hasil penelitian ini menggunakan. Analisis uji Annova didapatkan nilai P Value yang ditunjukkan oleh nilai Asymp. Sig adalah 0,005 yang berarti ada efek ekstrak daging buah ubi ungu (Ipomea batatas $l$ ) dapat menurunkan kadar kolesterol total pada tikus wistar yang mengalami dislipidemia.
\end{abstract}

Kata Kunci : Kolesterol, Ekstrak ubi ungu, tikus.

\section{ABSTRACT}

Introduction: Hypercholesterolemia and oxidative stress are still a health problem to date because they are associated with the emergence of cardiovascular disorders with various complications. Indonesian people have utilized many types of plants that can be used as alternatives to support health. In several studies, several plants have been found that can reduce blood cholesterol levels, one of which is purple yam (Ipomea batatas). Objective: To find out how the effect of purple sweet potato fruit extract (Ipomea batatas) can reduce total cholesterol levels in wistar rats that experience dyslipidemia. Method: This study was a True experimental study, with the research design used was the Post Test Only Control Group Design. Research Results: The results of this study use. Annova test analysis obtained the value of $P$ Value as indicated by the value of Asymp. Sig is 0.005 which means that there is an effect of purple sweet potato fruit extract (Ipomea batatas l) can reduce total cholesterol levels in wistar rats that have dyslipidemia. There is a correlation between the effect of purple sweet potato fruit extract (Ipomea batatas l) against decline total cholesterol levels in wistar rats that experience dyslipidemia.

Keywords: Cholesterol, Extract purple yams, mice.. 


\section{Pendahuluan}

Hiperkolesterolemia dan stres oksidatif masih merupakan masalah kesehatan hingga kini karena berkaitan dengan timbulnya kelainan kardiovaskular dengan berbagai komplikasi. Dislipidemia akan menyebabkan peningkatan dan aktivasi terhadap enzim $\mathrm{NADH} / \mathrm{NAD}(\mathrm{P}) \mathrm{H}$ oxidase, sehingga terjadi peningkatan produksi anion superoxide, yang merupakan salah satu radikal bebas penyebab stres oksidatif. $^{1}$

Aterosklerosis merupakan proses radang kronis dalam dinding pembuluh darah, yang menyebabkan berbagai komplikasi dan keluhan klinis. ${ }^{2,3}$ Stres oksidatif yang disertai dengan peningkatan kolesterol, akan memicu oksidasi LDL yang akan memperburuk inflamasi dan aterosklerosis. Peningkatan kadar kolesterol serum (hiperkolesterolemia) merupakan salah satu tanda gangguan metabolisme lipid (dislipidemia). Konsekuensi utama hiperkolesterolemia adalah peningkatan risiko terjadinya $\mathrm{PJK}$ (penyakit jantung koroner). ${ }^{4}$ Data WHO (World Health Organization) tahun 2011 memperlihatkan PJK sebagai penyebab kematian pertama di dunia, sedangkan di Indonesia merupakan penyebab kematian ke $8 .^{5}$

Bahan makanan yang mengandung flavonoid seperti sayursayuran, buah-buahan dan umbiumbian, diyakini dapat mencegah berbagai penyakit yang berkaitan dengan stres oksidatif.Flavonoid dapat bersifat sebagai antioksidan dengan cara menangkap radikal bebas, sehingga sangat penting dalam mempertahankan keseimbangan antara oksidan dengan antioksidan di dalam tubuh. ${ }^{6}$ Flavonoid mampu memperbaiki fungsi endotel pembuluh darah, dapat mengurangi kepekaan LDL terhadap pengaruh radikal bebas. ${ }^{7,8}$ Dapat juga bersifat hipolipidemik, anti inflammasi serta sebagai antioksidan. ${ }^{9,10}$

Flavonoid adalah antioksidan eksogen yang telah dibuktikan bermanfaat dalam mencegah kerusakan sel akibat stres oksidatif. Mekanisme kerja dari flavonoid sebagai antioksidan bisa secara langsung maupun secara tidak langsung. Flavonoid sebagai antioksidan secara langsung adalah dengan mendonorkan ion hidrogen sehingga dapat menetralisir efek toksik dari radikal bebas. Flavonoid sebagai antioksidan secara tidak langsung yaitu dengan meningkatkan ekspresi gen antioksidan endogen melalui beberapa mekanisme.

Masyarakat Indonesia telah banyak memanfaatkan berbagai jenis tanaman yang dapat digunakan sebagai alternatif untuk menunjang kesehatan, namun sebagian masyarakat Indonesia belum sepenuhnya mengetahui jenis, manfaat ataupun cara penggunaan tanaman obat tersebut . ${ }^{11}$

Dalam beberapa penelitian telah di temukan beberapa tanaman yang dapat menurunkan kadar kolesterol darah, salah satunya adalah Ubi ungu (Ipomea batatas). Kandungan antosianin yang tinggi pada ubi jalar ungu mempunyai stabilitas yang tinggi dibanding antosianin dari sumber lain. Itulah sebabnya tanaman ini menjadi pilihan yang lebih sehat dan sesuai dengan alternatif pewarna alami.$^{12}$ 
Kadar antosianin dalam ubi ungu (Ipoema batatas L) sekitar $90-96 \%$ dari total senyawa fenol. Senyawa fenol yang digolongkan sebagai flavonoid itu merupakan bagian dari antosianin. Pigmen tersebut berperan penting dalam pewarnaan merah hingga biru pada beberapa bunga, buah, dan daun. Sifat antosianin yang polar dapat larut pada pelarut polar yaitu etanol, aceton, dan air. ${ }^{13}$ Berdasarkan hasil penelitian dari Fakultas Pertanian Unud di Bali ditemukan tumbuhan ubi jalar ungu yang umbinya mengandung antosianin cukup tinggi yaitu berkisar antara 110mg - $210 \mathrm{mg} / 100$ $\operatorname{gram} .^{14}$

\section{METODE PENELITIAN Jenis Penelitian}

Penelitian ini merupakan penelitian True experimental, dengan rancangan penelitian yang digunakan adalah Post Test Only Control Group Design, yaitu jenis penelitian yang hanya melakukan pengamatan terhadap kelompok kontrol dan perlakuan setelah diberi suatu tindakan.

Penelitian dilaksanakan di Laboratorium Terpadu Fakultas Kedokteran Universitas Muhammadiyah Sumatera Utara untuk pelaksanaan kegiatan penelitian, pembuatan ekstrak ubi ungu dilalukan di Laboratorium Biokimia Fakultas Kedokteran Universitas Muhammadiyah Sumatera Utara, pengambilan sampel darah dilakukan di Laboratorium Farmakologi Fakultas Kedokteran Universitas Muhammadiyah Sumatera Utara dan pemeriksaan trigliserida dilakukan di
Laboratorium Kesehatan Daerah Sumatera utara Populasi penelitian adalah tikus jantan galur wistar putih (Rattus norvegicus) yang didapatkan dari Laboratorium Hewan Farmakologi Fakultas Kedokteran

Teknik pengumpulan data dilakukan dengan cara memberikan perlakuan kepada hewan coba tikus jantan galur wistar (Rattus novergicus), yaitu tikus tersebut dibuat dalam keadaan dislipidemia dengan diinduksi kuning telur puyuh. Data yang digunakan adalah data primer.

Ubi jalar ungu (Ipomoea batatas L.) Dibeli di transmart carefour yang bersumber dari organic simalem

\section{Persiapan Bahan Uji}

A. Ekstrak Ubi Jalar Ungu

Ekstrak ubi jalar ungu (Ipomoea batatas L.) dibuat dengan metode maserasi. Ubi jalar ungu (Ipomoea batatas L.) sebanyak 1 $\mathrm{kg}$ dipotong kecil-kecil lalu dijemur hingga kering. 300 gram ubi jalar ungu yang sudah kering ditambahkan dengan 6 liter etanol 70\%, kemudian dimasukkan ke dalam toples kaca, diaduk lalu didiamkan selama 3 hari. Campuran tersebut kemudian diserkai, hasil serkaian disebut dengan maserat 1. Ekstrak ubi ungu kemudian diuapkan pelarutnya dengan rotary evaporator pada suhu $50^{\circ} \mathrm{C}$. Ekstrak diberikan $1500 \mathrm{mg} / \mathrm{kgBB} / \mathrm{hari}$ dan $100 \mathrm{mg} / \mathrm{kgBB} / \mathrm{hari}$ setelah induksi kuning telur dihentikan

B. Kuning telur puyuh Bahan yang digunakan untuk meningkatkan kadar kolesterol 
total adalah kuning telur. Cara pembuatannya ialah dengan memisahkan kuning telur puyuh dari putihnya kemudian diemulsi dengan cara mengocok secara perlahan. Dosis yang diberikan pada tikus yaitu $10 \mathrm{ml} / \mathrm{kgBB}$. Pemberian pakan tinggi lemak sebanyak 1 kali sehari selama 14 hari.

Penentuan dosis untuk ekstrak ubi ungu pada penelitian ini berdasarkan rumus konversi dosis manusia dengan berat badan $70 \mathrm{~kg}$ diterapkan pada tikus dengan berat badan 200 gr sesuai table konversi Laurance-barcharch, yaitu dengan faktor konversi 0,018 .

Seluruh sampel tikus yang tersedia dibagi menjadi 4 kelompok penelitian dengan tektik simple random sampling. Dalam penelitian ini ada 1 kelompok kontrol negatif (K1), 1 kelompok kontrol positif (K2), dan 2 kelompok perlakuan (P1, P2) sebagai berikut :

1. kontrol negatif (K1) : kelompok tikus (Rattus novergicus L.) hanya diberikan aquabidest

2. kontrol positif (K2) : kelompok tikus (Rattus novergicus L.) hanya diberikan induksi kuning telur puyuh $10 \mathrm{ml} / \mathrm{kgBB} / \mathrm{hari}$

3. perlakuan 1 (P1) : kelompok tikus (Rattus novergicus L.) diberikan induksi kuning telur puyuh $10 \mathrm{ml} / \mathrm{kgBB} / \mathrm{hari}$ dengan ekstrak ubi jalar ungu (ipomoea Batatas L.) $150 \mathrm{mg} / \mathrm{kgBB} / \mathrm{hari}$

4. perlakuan $2(\mathrm{P} 2)$ : kelompok tikus (Rattus novergicus L.) diberikan induksi kuning telur puyuh $10 \mathrm{ml} / \mathrm{kgBB} / \mathrm{hari}$ dengan ekstrak ubi jalar ungu (ipomoea Batatas L. ) $100 \mathrm{mg} / \mathrm{kgBB} / \mathrm{hari}$
Penelitian ini mendapat persetujuan etik penelitian kesehatan dari Fakultas Kedokteran Universitas Muhammadiyah Sumatera Utara No.211/KEPK/FKUMSU/2019

untuk menggunakan hewan sebagai subjek penelitian. Penelitian ini merupakan penelitian True experimental, dengan rancangan penelitian yang digunakan adalah Post Test Only Control Group Design, yaitu jenis penelitian yang hanya melakukan pengamatan terhadap kelompok kontrol dan perlakuan setelah diberi suatu tindakan.

Penelitian ini terdiri dari 4 kelompok yaitu kelompok kontrol negatif (K1), kelompok kontrol Positif (K2), Kelompok Perlakuan 1 (P1) dan kelompok perlakuan 2 (P2). Hasil penilian pada masing-masing kelompok ditampilkan berdasarkan pada tabel dibawah ini

Tabel 4.1 Data kolesterol total tikus wistar

\begin{tabular}{|c|c|c|c|c|}
\hline $\begin{array}{c}\text { Kelom } \\
\text { pok }\end{array}$ & $\begin{array}{c}\text { Nom } \\
\text { or } \\
\text { Sam } \\
\text { pel }\end{array}$ & $\begin{array}{c}\text { Koles } \\
\text { terol } \\
\text { Total } \\
\text { (mg/dl } \\
\text { ) }\end{array}$ & $\begin{array}{c}\text { Re } \\
\text { rat } \\
\mathbf{a}\end{array}$ & $\begin{array}{c}\text { SD } \\
(32- \\
68)\end{array}$ \\
\hline \multirow{6}{*}{$\begin{array}{c}\text { Kontrol } \\
\text { negatif }\end{array}$} & $\begin{array}{l}\mathrm{K} 1 \\
\text { (1) }\end{array}$ & 59,00 & \multirow{6}{*}{$\begin{array}{c}53 \\
8\end{array}$} & $\begin{array}{l}\text { Nor } \\
\text { mal }\end{array}$ \\
\hline & $\begin{array}{l}\text { K1 } \\
\text { (2) }\end{array}$ & 43,00 & & $\begin{array}{l}\text { Nor } \\
\text { mal }\end{array}$ \\
\hline & $\begin{array}{l}\text { K1 } \\
\text { (3) }\end{array}$ & 32,00 & & $\begin{array}{l}\text { Nor } \\
\text { mal }\end{array}$ \\
\hline & $\begin{array}{l}\text { K1 } \\
\text { (4) }\end{array}$ & 62,00 & & $\begin{array}{l}\text { Nor } \\
\text { mal }\end{array}$ \\
\hline & $\begin{array}{l}\mathrm{K} 1 \\
(5)\end{array}$ & 68,00 & & $\begin{array}{l}\text { Nor } \\
\text { mal }\end{array}$ \\
\hline & $\begin{array}{l}\text { K1 } \\
(6)\end{array}$ & 59,00 & & $\begin{array}{l}\text { Nor } \\
\text { mal }\end{array}$ \\
\hline Kontrol & $\mathrm{K} 2$ (1) & 85,00 & 78 & Naik \\
\hline
\end{tabular}




\begin{tabular}{|c|c|c|c|c|}
\hline \multirow[t]{5}{*}{ positif } & K2 (2) & 97,00 & \multirow[t]{5}{*}{5} & Naik \\
\hline & $\mathrm{K} 2(3)$ & 87,00 & & Naik \\
\hline & $\mathrm{K} 2(4)$ & 51,00 & & $\begin{array}{c}\text { Norm } \\
\text { al }\end{array}$ \\
\hline & $\mathrm{K} 2(5)$ & 75,00 & & Naik \\
\hline & K2 (6) & 76,00 & & Naik \\
\hline \multirow{6}{*}{$\begin{array}{l}\text { Perla } \\
\text { kuan } 1\end{array}$} & P1 (1) & 48,00 & \multirow{6}{*}{$\begin{array}{c}44, \\
3\end{array}$} & $\begin{array}{c}\text { Norm } \\
\text { al }\end{array}$ \\
\hline & P1 (2) & 35,00 & & $\begin{array}{c}\text { Norm } \\
\text { al }\end{array}$ \\
\hline & P1 (3) & 38,00 & & $\begin{array}{c}\text { Norm } \\
\text { al }\end{array}$ \\
\hline & P1 (4) & 40,00 & & $\begin{array}{c}\text { Norm } \\
\text { al }\end{array}$ \\
\hline & P1 (5) & 55,00 & & $\begin{array}{c}\text { Norm } \\
\text { al }\end{array}$ \\
\hline & P1 (6) & 50,00 & & $\begin{array}{c}\text { Norm } \\
\text { al }\end{array}$ \\
\hline \multirow{6}{*}{$\begin{array}{c}\text { Perla } \\
\text { kuan } 2\end{array}$} & $\mathrm{P} 2(1)$ & 49,00 & \multirow{6}{*}{$\begin{array}{c}57 \\
8\end{array}$} & $\begin{array}{c}\text { Norm } \\
\text { al }\end{array}$ \\
\hline & $\mathrm{P} 2(2)$ & 60,00 & & $\begin{array}{c}\text { Norm } \\
\text { al }\end{array}$ \\
\hline & P2 (3) & 55,00 & & $\begin{array}{c}\text { Norm } \\
\text { al }\end{array}$ \\
\hline & $\mathrm{P} 2(4)$ & 70,00 & & Naik \\
\hline & $\mathrm{P} 2(5)$ & 41,00 & & $\begin{array}{c}\text { Norm } \\
\text { al }\end{array}$ \\
\hline & P2 (6) & 72,00 & & Naik \\
\hline
\end{tabular}

\begin{tabular}{llll}
\hline $\begin{array}{l}\text { Kelomp } \\
\text { ok }\end{array}$ & Sig. & $\mathbf{P}$ & $\begin{array}{l}\text { Kemakna } \\
\text { an }\end{array}$ \\
\hline K1 vs K2 & $\begin{array}{l}0,00 \\
8\end{array}$ & $\begin{array}{l}<0,0 \\
5\end{array}$ & Signifikan \\
\hline K1 vs P1 & $\begin{array}{l}1,00 \\
0\end{array}$ & $\begin{array}{l}>0.0 \\
5\end{array}$ & $\begin{array}{l}\text { Tidak } \\
\text { signifikan }\end{array}$ \\
\hline \multirow{2}{*}{ K1 vs P2 } & $\begin{array}{l}1,00 \\
0\end{array}$ & $\begin{array}{l}>0.0 \\
5\end{array}$ & $\begin{array}{l}\text { Tidak } \\
\text { signifikan }\end{array}$ \\
\hline K2 vs P1 & $\begin{array}{l}0,00 \\
8\end{array}$ & $<0.0$ & Signifikan \\
\hline \multirow{2}{*}{ K2 vs P2 } & $\begin{array}{l}0,00 \\
7\end{array}$ & $\begin{array}{l}<0.0 \\
5\end{array}$ & Signifikan \\
\hline P1 vs P2 & $\begin{array}{l}1,00 \\
0\end{array}$ & $\begin{array}{l}>0.0 \\
5\end{array}$ & $\begin{array}{l}\text { Tidak } \\
\text { signifikan }\end{array}$ \\
\hline
\end{tabular}

Dari tabel di atas, terdapat perbedaan dalam penilaian kadar kolesterol total pada tikus di setiap kelompok. Pada kelompok kontrol negatif (K1) gambaran kadar kolesterol total tikus masih normal dan pada kelompok kontrol positif terdapat kenaikan kadar kolesterol total dikarenakan dari pemberian kuning telur puyuh. Namun, pada kelompok perlakuan 1 terdapat 6 sampel perlakuan yang mengalami penurunan sedangkan perlakuan 2 terdapat 4 sampel yang mengalami penurunan kadar kolesterol total dengan tingkatan yang berbeda dan 2 sampel yang mengalami kenaikan..

\section{HASIL PENELITIAN}

Berdasarkan data gambaran kolesterol total tersebut, dilakukan uji normalitas dan didapatkan hasil $0,200$ ( $p>0,05)$. Oleh karena itu, data dinyatakan berdistribusi normal dan dilanjutkan dengan menggunakan uji One Way Anova.

Tabel 4.2 Hasil Uji Annova kelompok K1, K2, P1, P2

Dari tabel di atas, didapatkan hasil bahwa tidak terdapat perbedaan yang signifikan antara kelompok kontrol negatif dengan kontrol positif, kelompok perlakuan 1 dan kelompok perlakuan 2. Hal ini menunjukkan bahwa kurangnya pengaruh pemberian ekstrak ubi ungu 150 dan 100 terhadap penurunan kadar kolesterol total tikus yang diinduksi kuning telur puyuh.

\section{PEMBAHASAN}

Penelitian ini menggunakan tikus wistar yang dibagi menjadi 4 kelompok yaitu kelompok negatif (K1), kelompok positif (K2), 
kelompok perlakuan 1 (P1) dan kelompok perlakuan 2 (P2). Dimana pada kelompok positif, kelompok perlakuan 1 dan kelompok perlakuan 2 yang diinduksi dengan kuning telur puyuh.

Berdasarkan hasil pengamatan penurunan kadar kolesterol total tikus dapat diketahui bahwa pada kelompok kontrol negatif (K1) dengan kelompok positif (K2) memiliki nilai $\mathrm{P}<0,05$ yang artinya tidak ada perbedaan yang bermakna.Pada kelompok kontrol negatif (K1) dengan kelompok perlakuan 1 (P1) memiliki nilai $\mathrm{P}>0,05$ yang artinya ada perbedaan yang bermakna. Pada kelompok kontrol negatif (K1) dengan kelompok perlakuan 2 (P2) memiliki nilai $\mathrm{P}>0,05$ yang artinya ada perbedaan yang bermakna. Pada kelompok kontrol positif (K2) dengan kelompok perlakuan 1 (P1) memiliki nilai $\mathrm{P}<0,05$ yang artinya tidak ada perbedaan yang bermakna. Pada kelompok kontrol positif (K2) dengan kelompok perlakuan 2 (P2) memiliki nilai $\mathrm{P}<0,05$ yang artinya tidak ada perbedaan yang bermakna. Pada kelompok kontrol perlakuan 1 (P1) dengan kelompok perlakuan 2 (P2) memiliki nilai $\mathrm{P}>0,05$ yang artinya ada perbedaan yang bermakna

Pada kelompok negatif (K1) yang diberikan aquabides terjadi penurunan total kolesterol secara bermakna.Pada kelompok positif (K2) yang diberi kuning telur puyuh selama 2 minggu secara berturut ternyata terjadi kenaikan kadar total kolesterol secara bermakna dan 1 kelompok yang mengalami kenaikan berupa kelompok K2 (4). Pada kelompok P1 yang diberikan ekstrak ubijalar ungu 150 dan kuning telur puyuh selama 2 minggu secara bergantian ternyata terjadi penurunan total kolesterol secara bermakna.Pada kelompok P2 yang diberikan ekstrak ubijalar ungu 100 dan kuning telur puyuh selama 2 minggu secara bergantian ternyata hanya sebagian yang terjadi penurunan total kolesterol secara bermakna

Rerata kadar kolesterol total pada kelompok positif meningkat terdapat 5 ekor tikus pada kelompok kontrol positif yang mengalami peningkatan kolesterol dan 1 ekor tkus K2(4) pada kelompok kelompok kontrol positif yang mengalami penurunan. Kelompok perlakuan P1 tidak terdapat tikus yang mengalami peningkatan. Kelompok perlakuan P2 terdapat 2 tikus yang mengalami peningkatan berupa P2(4) dan juga P2(6) mengalami kenaikan kadar kolesterol total. Peningkatan kadar kolesterol total tikus pada kelompok perlakuan 2 (P2) disebabkan oleh hal, yaitu adalah tikus kemungkinan mengalami stress. Stress pada tikus dapat terjadi karena proses pemberian makananan melalui sonde dalam jangka waktu lama, Stress dapat menyebabkan peningkatan asam lemak bebas serta meningkatkan sekresi VLDL yang berdampak pada peningkatan kadar kolesterol total. ${ }^{15}$ Berdasarkan literatur ubi jalar mengandung berbagai macam zat yang dapat menurunkan kadar kolesterol total darah. Flavonoid yang terkandung dalam daun ubi jalar, terkhususnya quercetin dapat menurunkan kadar kolesterol darah dengan cara meningkatkan ekskresi asam empedu. Flavonoid mengurangi 
sintesis kolesterol dengan cara menghambat aktivitas enzim acylCoA cholesterol acyl transferase (ACAT) pada sel HepG2 yang berperan dalam penurunan esterifikasi kolesterol pada usus dan hati, serta menghambat aktivitas enzim 3hiroksi-3metil-glutaril-CoA yang menyebabkan penghambatan sintesis kolesterol. Quercetin dapat menurunkan kadar kolesterol total dan kadar kolesterol LDL dengan cara menghambat sekresi apolipoprotein B pada sel $\mathrm{CaCo} 2$ dan menurunkan aktivitas microsomal triglyceride transfer protein (MTP) yang memiliki peran dalam pembentukkan lipoprotein dan mengkatalisa perpindahan lipid ke molekul APO B. Penelitian lain juga menyebutkan bahwa quercetin dapat menghambat aktivitas enzim HMGKoA reduktase, yaitu enzim yang berperan dalam pembentukkan kolesterol.

Berdasarkan hasil uji fitokimia pada ekstrak ubi ungu memiliki kandungan antosianin berupa flavonoid, terpenoid, dan alkaloid. Kandungan antioksidan tersebut memiliki kemungkinan untuk memperbaiki kadar kolesterol total Pada kelompok perlakuan 1 dan 2 menunjukkan bahwa ekstrak ubi ungu 150 dan 100 memiliki peranan dalam perbaikan penurunan kadar kolesterol total Pemberian ekstrak ubijalar ungu yang mengandung antosianin cukup tinggi, ${ }^{16}$ akan berfungsi sebagai antioksidan eksogen sehingga dapat meningkatkan total antioksidan. Antosianin yang merupakan pigmen alami memiliki rumus bangun dengan struktur phenolic sehingga dapat mentransfer atom hidrogen dari radikal bebas hydroxyl. Warna kebiruan pada tumbuh-tumbuhan merupakan salah satu ciri bahwa mengandung antosianin cukup tinggi ${ }^{17}$ seperti pada ubijalar ungu, sehingga pada tikus yang diberikan makanan tinggi kolesterol dapat memperkecil penurunan total antioksidan darah. Hal ini tentu disebabkan adanya khasiat antioksidan dari ekstrak ubi jalar ungu, yang akan menyebabkan penghematan pemakaian antioksidan endogen, karena antosianin yang terdapat pada ubijalar ungu secara in vitro terbukti dapat sebagai antioksidan, dengan metode DPPH. ${ }^{18}$ Penurunan serum kolesterol akibat pemberian antosianin ternyata melalui hambatan terhadap absorpsi kolesterol dan asam empedu dalam usus. Hal ini dibuktikan dengan penelitian pada tikus percobaan yang diberikan nasunin suatu antosianin dari terong, ternyata dapat menurunkan total kolesterol serum dan meningkatkan HDL. ${ }^{19}$ Hasil penelitian ini sesuai dengan penelitian tersebut.

\section{KESIMPULAN}

Berdasarkan hasil penelitian yang dilakukan, dapat disimpulkan bahwa pemberian ekstrak ubi ungu dengan dosis $150 \mathrm{mg} / \mathrm{KgBB}$ selama 14 hari pada tikus yang diinduksi kolesterol dengan kuning telur puyuh $10 \mathrm{~mL} / \mathrm{KgBB}$ secara signifikan dapat menurunkan kadar kolesterol total serum dan pemberian ekstrak ubi ungu dengan dosis 100 $\mathrm{mg} / \mathrm{KgBB}$ selama 14 hari pada tikus yang diinduksi kolesterol dengan kuning telur puyuh $10 \mathrm{~mL} / \mathrm{KgBB}$ tidak signifikan untuk menurunkan kadar kolesterol total serum. 


\section{REFERENSI}

1. Cai H, Harrison DG. Endothelial Dysfunction in Cardiovascular Diseases: The Role of Oxidant Stress. Circulation Research. 2000;87:840-65.

2. Phipps RP. Atherosclerosis: the emerging role of infl a mmation and CD 40-CD 40 ligand system. Proc Natl Acad Sci U S A/ 2000;97:6930-2

3. Arenillas JF, Alvarez-Sabin J, Molina CA. Progression of Symptomatic Intracranial Large Artery Athrosclerosis Is Associated With a Proinfl ammatory State and Impaired Fibrinolysis. Stroke. 2008;39:1456

4. Lewington $\mathrm{S}$, Clarke $\mathrm{R}$, Qizilbash N, Peto R, Collins R; Prospective Studies Collaboration.Lancet. 2002 Dec 14;360(9349):1903-13. Erratum in: Lancet. 2003 Mar 22;361(9362):1060.

5. WHO (2011) Top 10 Causes of Death.

Www.who.int/mediacentre/facts heets/fs310/en/ diakses 25 April 2014

6. Koncazak I, Okuno S, Yoshimoto M,Yamakawa O. Caffeoylquinic Acids Generated In Vitro in highanthocyaninAccumulating Sweet potato Cell Line. Journal of Biomedicine and Biotechnology. 2004;5:28792.

7. Kwon SH. Anti-obesity and Hypolipidemik Effects of Black Soybean Anthocyanins. Journal of medicinal Food. 2007;10(3):552-6
8. Micallef $\mathrm{M}, \mathrm{L} \mathrm{e}$ xis $\mathrm{L}$, Lewandowski P. Red wine consumption increases

9. http://yogya.litbang.pertanian.go .id

10. I Wayan S, I Made J. Ekstrak Air Daun Ubijalar Ungu Memperbaiki Profil Lipid dan Meningkatkan Kadar SOD Darah Tikus yang Diberi Makanan Tinggi Kolesterol [skripsi]. Bali: Universitas Udayana;2012.

11. Syarif P, Suryoutomo B, Soeprapto, H. 2011, Deskripsi dan manfaat tanaman obat di pedesaan sebagai upaya pemberdayaan apotik hidup. Jurnal Ilmu Pengetahuan dan Teknologi Universitas Pekalongan 21(1):20-3

12. Dwi Siswoyo, dkk. 2013. Ilmu Pendidikan. Yogyakarta: UNY Press.

13. Jurnal Teknologi Pangan Vol.2 No.1 November 2011

14. Lee, J., Durst R.W. dan Wrolstad R.E. 2005. Determination of total monomeric anthocyanin pigment content of fruit juices, beverages, natural colorants, and wines by the ph differential method: collaborative study. Journal of Association of Official Analytical Chemists International 88 (5) : 12691278.

15. Astriana Y. Peningkatan Intensitas Warna Kuning Telur Dan Kadar Omega-3 Pada Burung Puyuh Yang Diberi Pakan Undur-Undur Laut (Emerita Sp). 2013.

16. Prior RL. 2003. Fruits and vegetables in the prevention of cellular oxidative damage. Am J 
Clin Nutr, 78 (3): 570s-578s

17. Huang DJ, Lin CD, Chen HJ, Lin YH. 2004. Antioxidant and antiproliferative activities of sweet potato (Ipomoea batatas L. Lam Tainong 57) constituents. Bot. Bull. Acad. Sin. 45: 179186.

18. Fumio K, Kibaru I. 1994. Effects of Dietary Nasunin on the Serum Cholesterol Level in Rats. Journal Of Biocience Biotechnology and Biochemistry. 58 (3): 570-571.

19. Kathleen MB, Mayes PA. Sintesis, Pengangkutan, dan Ekskresi Kolesterol. Dalam: Murray RK, Granner DK, Rodwell VW, editor. Biokimia harper 27th ed. Jakarta: EGC; 2006.p.248. 